
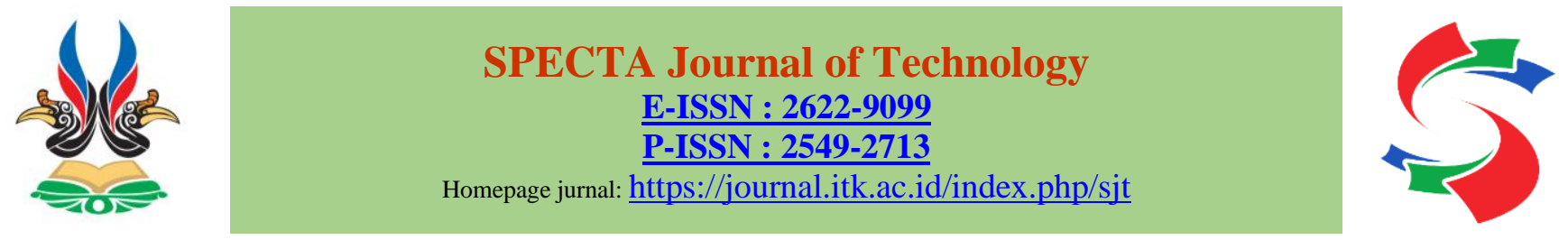

\title{
Perancangan dan Evaluasi UI/UX Aplikasi E-Learning Berbasis Gamification Menggunakan Metode Cognitive Walktrough
}

\author{
M. Gilvy Langgawan Putra ${ }^{1}$, Wira Maulana ${ }^{2}$ \\ ${ }^{1,2}$ Program Studi Sistem Informasi, Institut Teknologi Kalimantan, Balikpapan. \\ Email: 10171075@student.itk.ac.id
}

\begin{abstract}
E-Learning is an online learning medium using electronic networks. Currently, there are many E-Learning spread throughout the world, but something is needed that can increase student motivation. Using the Gamification method, this method adopts concepts and thoughts in a game which are then applied to non-game activities and with a good Gamification-based E-Learning user interface design, besides being able to help expand the media in learning it can also increase learning interest and student motivation in study. To find out whether the results of the user interface design are good and in accordance with the needs, an evaluation is needed. There are many evaluation methods, one of which is the cognitive walkthrough method. This method is carried out with several respondents doing the tasks that have been given as well as interviews with respondents. Through this research it is known that the most problems arise in grade three with a low level of seriousness. The type of problem that is most often found is Text and Icon which appear in grades four, three, and two to be precise in task number three, four, five, six, and seven. Then the most problems were found in task number three and six. The numbers shown for each problem found are relatively small so that they do not have much effect on the running of the system.
\end{abstract}

Keywords: cognitive walktrough, e-learning, gamification.

\begin{abstract}
Abstrak
E-Learning merupakan sebuah media pembelajaran secara online dengan menggunakan jaringan elektronik. Saat ini telah banyak E-Learning yang tersebar diseluruh dunia, akan tetapi dibutuhkan suatu hal yang dapat meningkatkan motivasi belajar para pelajar. Menggunakan metode Gamification yang mana metode ini mengadopsi konsep serta pemikiran pada suatu permainan yang kemudian diterapkan kedalam aktivitas bukan permainan dan dengan rancangan desain user interface E-Learning berbasis Gamification yang baik, selain dapat membantu memperluas media dalam pembelajaran juga dapat meningkatkan minat belajar serta motivasi pelajar dalam belajar. Untuk mengetahui apakah hasil rancangan desain user interface telah baik serta sesuai dengan kebutuhan, diperlukan sebuah evaluasi. Terdapat banyak metode evaluasi, salah satunya yaitu metode Cognitive Walktrough. Metode ini dilakukan dengan beberapa responden melakukan tugas yang telah diberikan serta wawancara kepada responden. Melalui penelitian ini diketahui bahwa masalah paling banyak muncul pada grade tiga dengan tingkat keseriusan rendah. Jenis Masalah yang paling sering ditemukan yaitu Text and Icon dengan yang muncul pada grade empat, tiga, dan dua tepatnya pada tugas nomor tiga, empat, lima, enam, dan tujuh. Kemudian masalah ditemukan paling banyak pada tugas nomor tiga dan enam. Angka-angka yang ditunjukan pada setiap masalah yang ditemukan terbilang kecil sehingga tidak banyak berpengaruh pada jalannya sistem.
\end{abstract}

Kata Kunci: cognitive walktrough, e-learning, gamification. 


\section{Pendahuluan}

Terdapat banyak faktor yang berpengaruh dalam menghasilkan pembelajaran yang baik, salah satunya adalah media yang digunakan dalam proses belajar mengajar. Pada situasi yang terjadi saat ini, sebagai dampak dari pandemi yang berlangsung mengakibatkan para pelajar dan pengajar diharuskan untuk menggunakan media yang dapat menunjang proses pembelajaran secara online. Sebab itu dengan menggunakan E-Learning yang merupakan proses pembelajaran media elektronik melalui jaringan komputer, proses belajar mengajar dapat dilakukan dalam jangkauan yang lebih luas kapan pun dan dimana pun.

Melalui hasil survei menggunakan kuesioner yang dilakukan kepada mahasiswa program studi sistem informasi, diketahui bahwa pentingnya penggunaan E-Learning untuk menunjang pembelajaran, dalam hal ini pada program studi sistem informasi. Selain itu dikarenakan motivasi belajar yang dimiliki oleh sebagian besar mahasiswa tidak cukup tinggi, diperlukan sebuah metode yang dapat digunakan untuk meningkatkan motivasi belajar mahasiswa. Kemudian dari data hasil kuesioner diketahui bahwa metode Gamification dapat mempengaruhi peningkatan minat belajar mahasiwa, metode Gamification sendiri merupakan sebuah metode dengan menggunakan unsur yang terdapat pada permainan dan digunakan pada bidang tertentu yang disesuaikan sehingga dapat membuat hal tersebut menjadi lebih menarik. Menggunakan metode Gamification dapat meningkatkan minat mahasiswa dalam pembelajaran melalui E-Learning, serta meningkatkan motivasi, keterlibatan dan kinerja dari mahasiswa. Dengan menerapkan E-Learning yang dipadukan dengan Gamification akan membantu lingkungan belajar yang dapat membuat peserta didikik merasa lebih dimotivasi, tertarik, dan juga terpancing untuk menyelesaikan tugas yang diberikan (Amriani, 2013).

Pada Penelitian ini dilakukan perancangan desain User Interface dari E-learning untuk memberikan gambaran kepada pengembang mengenai antarmuka yang ditampilkan pada sistem ini, hal ini juga untuk mengetahui apakah sistem yang dirancang telah sesuai dengan yang diharapkan. Selain itu juga dilakukan evaluasi dari User Interface yang telah dirancang. Evaluasi dilakukan untuk mengetahui apakah rancangan yang dihasilkan sudah baik dan dapat dioperasikan oleh pengguna dengan mudah, serta untuk mengetahui permasalahan atau kendala yang terdapat pada rancangan User Interface yang telah dibuat. User Interface dibuat dalam versi mobile dan desktop dengan menggunakan basis Gamification, sedangkan evaluasi dilakukan dengan metode Cognitive Walktrough yang merupakan salah satu metode dalam usability evaluation, metode ini dilakukan dengan melibatkan responden untuk melakukan tugas yang telah ditentukan. metode ini banyak digunakan karena tidak memerlukan banyak waktu dalam prosesnya dan berfokus pada pemahaman pengguna dalam mengeksplorasi User Interface yang dievaluasi. Pengguna akan melakukan tugas dengan teknik "trial and error" untuk menemukan problem atau permasalahan pada tugas yang diberikan. Metode ini menstimulasi proses kognitif pengguna ketika dia melakukan tugas-tugas yang diberikan secara berurutan (Bligard, 2013).

Responden pada evaluasi User Interface yaitu mahasiswa Sistem Informasi Institut Teknologi Kalimantan yang telah terbiasa melakukan pembelajaran menggunakan E-Learning atau pernah melakukan pembelajaran secara online.

\section{Metode}

Pada penelitian ini dibutuhkan sebuah alur metodologi untuk menentukan langkah dan proses dari penelitian yang dilakukan. Alur metodologi pada penelitian ini mencakup studi literatur, perancangan desain interface, perancangan skenario cognitive walktrought, pengambilan data, analisis hasil evaluasi, serta penarikan kesimpulan dan saran. berikut merupakan informasi mengenai Alur metodologi yang dilakukan pada penelitian ini. 


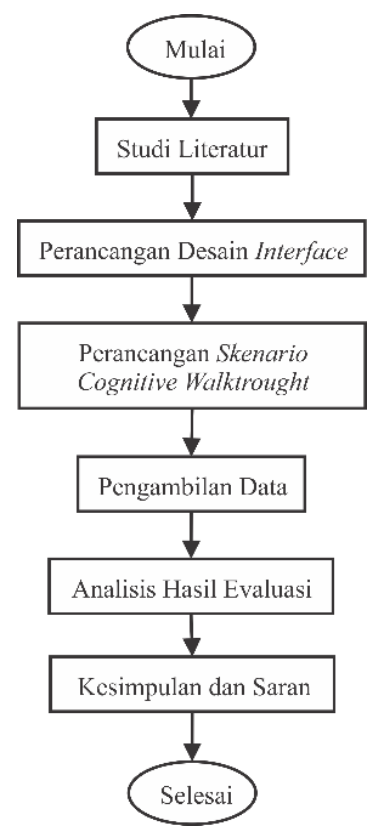

Gambar 1: Alur Metode Penelitian

\subsection{Studi Literatur}

Studi Literatur dilakukan untuk mencari dan menemukan landasan yang tepat sehingga dapat mendukung penelitian ini. Berikut merupakan Literatur yang mendukung penelitian.

\subsubsection{E-Learning}

Elektronik Learning mengandung beberapa pengertian yang sangat luas, sehingga terdapat banyak pakar yang menguraikan definisi dari E-Learning dari berbagai sudut pandang. Salah satunya yaitu $E$ Learning sebagai intruksi yang disampaikan oleh komputer yang dirancang untuk melakukan proses belajar mengajar secara individu atau sebuah tujuan dari suatu perusahaan. E-Learning dapat dijadikan sarana pembelajaran melalui rangkaian elektronik (LAN, WAN, atau internet) untuk menyampaikan materi pembelajaran, interaksi pengajar dan pelajar, serta bimbingan (Sari, 2016).

E-Learning sendiri lebih mengarah pada penggunaan teknologi internet untuk mengantarkan solusi yang dapat meningkatkan kualitas pembelajaran, pengetahuan, serta keterampilan. Sehingga dari pengertian yang telah diberikan dapat disimpulkan bahwa segala media pembelajaran yang menggunakan teknologi informasi (internet) yang bersifat online dan dapat memberikan pembelajaran serta interaksi antara pengajar dan pelajar merupakan sesuatu yang disebut E-Learning.

\subsubsection{Gamification}

Gamification merupakan sebuah konsep dimana mengaplikasikan pemikiran desain permainan kedalam suatu aplikasi non-game untuk membuat menjadi lebih menarik dan menyenangkan (Baldauf, 2017). Gabe Zichermann penulis dari buku "Game-based Marketing" mendefinisikan metode Gamification sebagai suatu proses yang menggunakan pemikiran permainan atau mekanisme untuk menarik minat audiences dan untuk menyelesaikan masalah. Karl Kapp yang merupakan penulis dari buku "The Gamification of Learning and instructions" mengartikan bahwa Gamification merupakan penggunaan dasar mekanisme dari permainan, estetis, dan pemikiran permainan untuk menarik, memotivasi aksi, mempromosikan pembelajaran, serta menyelesaikan masalah (Malas, 2016).

Istilah Gamification mulai dikenal secara luas setelah foursquare yang merupakan sebuah situs web jejaring social meledak dipasaran dengan fitur badge atau virtual item yang dimilikinya, namun jauh sebelum itu melihat dari definisi Gamification, secara tidak sadar metode ini telah lama diterapkan pada kehidupan nyata. Misalnya seorang guru yang memberikan hadiah kepada muridnya yang berhasil menjawab suatu pertanyaan dengan benar, seorang ibu yang menyuapi anaknya yang sulit makan 
dengan menganalogikan sendok makanan sebagai sebuah kereta api, atau sebuah promosi dari suatu toko yang memberikan hadiah kepada pelanggannya setelah pelanggan tersebut berhasil mengumpulkan stempel atau voucher belanja (Darmawan, 2020).

Gamification dapat menarik keuntungan dari keinginan manusia dalam mencapai cita-cita yang tinggi dan ingin diakui. Beberapa orang termotivasi untuk hadiah, sementara yang lainnya termotivasi oleh aktualisasi diri. Sama seperti pada permainan, banyak orang berupaya untuk mencapai peringkat yang tinggi ataupun hadiah yang ditawarkan, sehingga banyak orang terus-menerus melakukan interaksi pada sistem yang mengadopsi metode ini (Darmawan, 2020).

\subsubsection{Cognitive Walktrough}

Cognitive Walktrough merupakan sebuah metode yang berfokus pada eksplorasi yang didasarkan pada teori pembelajaran eksploratif. Pada metode ini pengguna atau responden akan melakukan task atau tugas dengan Teknik trial and error, yang menggambarkan simulasi kognitif responden saat melakukan task atau tugas tertentu. Metode Cognitive Walktrough mampu menilai apakah pengetahuan dari responden sesuai dengan petunjuk terkait penggunaan sistem yang mengarah pada tujuan atau tindakan yang tepat (Solikhin, 2018).

Metode Cognitive Walktrough pada awalnya dikembangkan untuk mengarahkan teori kognitif menjadi lebih dekat dengan pengembangan desain yang praktis serta evaluasi dari User Interface. Terdapat tiga versi dari metode ini, pada versi pertama disebutkan bahwa evaluator memberikan tugas yang representasif dalam menyelesaikan task serta memperkirakan latar belakang calon pengguna, versi kedua metode ini dikembangkan dengan lebih kompleks dan rinci sehingga pertanyaan yang digunakan juga menjadi terlalu umum dan pada akhirnya dianggap terlalu rumit, sulit diterapkan dan memakai lebih banyak waktu dalam penggunaannya. Pada versi ketiga metode Cognitive Walktrough dikembangkan oleh Lewis dan Wharton, pada versi ini terdapat tiga tahapan yaitu Preparation, Analysis, dan follow up. pada tahap preparation dilakukan identifikasi pengguna, mendefinisikan task yang akan dievaluasi, menentukan urutan task yang akan dilakukan, serta mengetahui bagaimana User Interface memberikan informasi saat tugas diberikan. Pada tahap analysis hasil dari tahapan preparation diproses, proses dilakukan dengan memilih task yang akan dilakukan, dan evaluator akan memberikan pertanyaan setiap task yang diberikan. Pada tahap terakhir yaitu dan follow up hasil perbaikan didapatkan sehingga dapat dijadikan sebagai rekomendasi perbaikan (Akbar, 2019).

Menurut Bligard perlu dilakukan peningkatan Cognitive Walkthrough untuk mencoba meniadakan defisiensi dalam versi ketiga Cognitive Walkthrough, hal ini bertujuan untuk mengembangkan metode yang dapat mendeteksi serta mengidentifikasi dengan baik masalah yang terdapat pada interface serta memberikan gambaran tentang jenis masalah dan tingkat keseriusan masalah yang terjadi. Pada versi Bligard terdapat tiga tambahan pada metode ini, yaitu pertanyaan dibagi menjadi 2 tingkat, yakni fungsi dan operasi, penilaian diberikan untuk menentukan keberhasilan dan kegagalan yang kemudian dimasukan ke dalam beberapa kategori masalah, dan terakhir analisis dilakukan dalam bentuk matriks untuk mengetahui gambaran umum yang lebih baik serta agar dapat dibandingkan dengan interface yang berbeda (Akbar, 2019).

\subsection{Perancangan Desain Interface}

Pada perancangan desain interface atau antarmuka dilakukan perancangan desain yang disesuaikan dengan dokumen SRS dan SDD yang telah ada, pada interface sistem informasi yang bernama ESIKA ini dirancang dengan menggunakan software desain. Sistem informasi ini dirancang dengan 2 versi, yaitu versi mobile dan desktop, yang dapat diakses oleh 3 aktor berbeda, yaitu dosen, mahasiswa, dan admin.

\subsection{Perancangan Skenario Cognitive Walktrough}

Pada perancangan scenario dilakukan beberapa tahapan, yaitu menentukan task, membuat Hierarchical Task Analysis, menentukan jenis masalah, dan keseriusan masalah. 
Tabel 1: Tugas

\begin{tabular}{llll}
\hline & Nomor Tugas & Tugas & Grade \\
\hline 1 & Melakukan Pendaftaran & 1 \\
2 & Melakukan Login & 1 \\
3 & Mencari Kelas & 2 \\
4 & Mengakses Materi & 3 \\
5 & Mengerjakan Ujian & 3 \\
6 & Mengerjakan Challenge & 3 \\
7 & Mengambil Reward & 4 \\
\hline
\end{tabular}

Pada Tabel 1 ditunjukan tugas yang akan dilakukan oleh responden serta tingkatan dari tugas. Grade 1 menunjukkan bahwa tugas tersebut sangat penting dan harus dikerjakan, jika tugas ini tidak dikerjakan maka tidak akan dapat melakukan tugas yang lain. Grade 2 juga merupakan tugas yang penting dan harus dikerjakan. Pada Grade 3 merupakan tugas yang tidak terlalu penting, namun dapat menunjang jalannya sistem. Sedangkan pada Grade 4 jika tugas tidak dikerjakan tidak akan berpengaruh pada jalannya sistem.

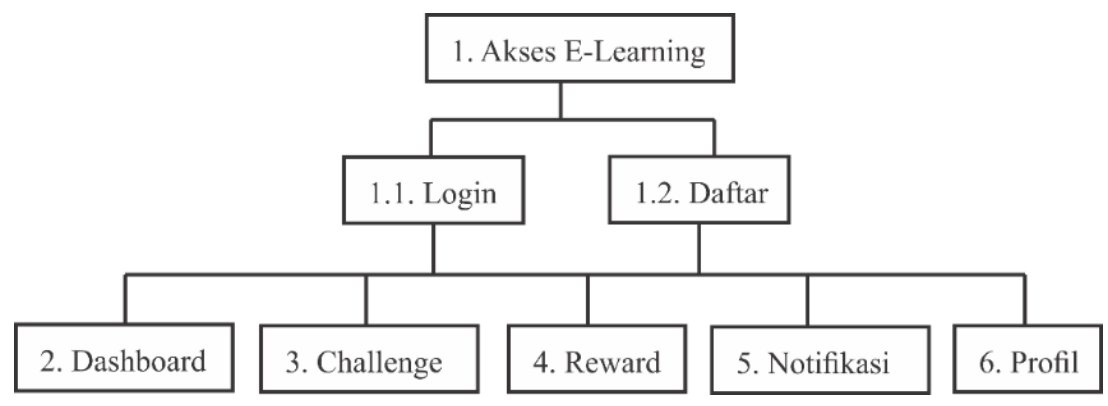

Gambar 2: Hierarchical Tugas Analysis Menu Utama

Setelah tugas ditentukan kemudian dijelaskan spesifikasi tugas menggunakan bantuan Hierarchical tugas analysis. Pada Gambar 2 menunjukan menu utama yang terdapat pada sistem, yaitu setelah mengakses E-learning, user dapat memilih untuk melakukan daftar jika belum memiliki akun, dan login, jika telah memiliki akun. Terdapat juga menu Dashboard, Challenge, Reward, Notifikasi, dan Profil.

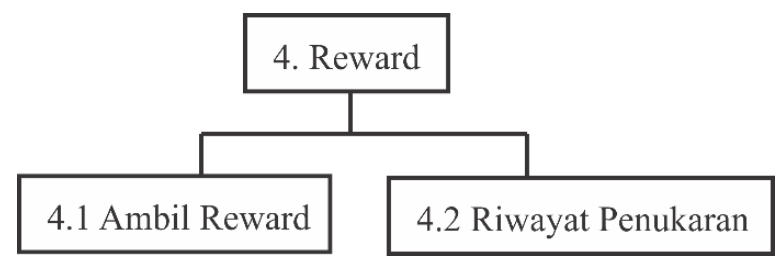

Gambar 3: Hierarchical Tugas Analysis Menu Reward

Pada Gambar 3 merupakan fungsi yang terdapat pada menu Reward. Terdapat Ambil Reward untuk mengambil reward yang diinginkan, dan Riwayat Penukaran untuk melihat reward apa saja yang telah diambil dan ditukarkan dengan poin yang dimiliki.

Tabel 2: Jenis masalah

\begin{tabular}{ll}
\hline \multicolumn{1}{c}{ Jenis Masalah } & \multicolumn{1}{c}{ Penjelasan } \\
\hline (U) User & Masalah yang ditimbulkan dari pengalaman dan pengetahuan pengguna \\
(H) Hidden & Masalah yang ditimbulkan dari tampilan kurang atau tidak memberikan \\
& keterangan bahwa fungsi itu ada dan bisa digunakan \\
(T) Text and Icon & $\begin{array}{l}\text { Penampilan, penempatan, konten, dan warna dari sistem yang sulit } \\
\text { dimengerti atau dapat disalah artikan }\end{array}$ \\
(I) Sequence & Fungsi dan operasi harus dilakukan dengan urutan yang tidak biasa \\
\hline
\end{tabular}


(P) Physical Demand

(F) Feedback
Tampilan yang membutuhkan ketangkasan atau keahlian lebih dari pengguna (contohnya kecepatan dan kekuatan)

Masalah yang ditimbulkan dari sistem tidak memberikan keterangan indikasi terhadap apa yang dilakukan pengguna

Sumber: Akbar, 2019

Pada Tabel 2 menunjukan jenis tipe masalah yang mungkin terdapat pada user interface. Terdapat 6 tipe masalah yang mungkin terjadi, yaitu User, Hidden, Text and Icon, Sequence, Physical Demand, dan Feedback.

Tabel 3: Keseriusan masalah

\begin{tabular}{lll}
\hline \multicolumn{1}{c}{ Nilai } & \multicolumn{1}{c}{ Nilai dalam Kata } & \multicolumn{1}{c}{ Penjelasan } \\
\hline 5 & Iya & Kemungkinan berhasil besar \\
4 & Mungkin Iya & Mungkin dapat berhasil \\
3 & Tidak tahu & Antara berhasil dan tidak \\
2 & Mungkin Tidak & Kemungkinan berhasil kecil \\
1 & Tidak & Sangat sulit untuk berhasil \\
\hline Sumber: Akbar, 2019 &
\end{tabular}

Pada Tabel 3 menunjukan tingkat keseriusan masalah yang mungkin terdapat pada user interface. Nilai menunjukan indikator seberapa serius masalah yang terjadi, semakin besar nilai yang diberikan maka semaki kecil tingkat keseriusan masalah yang terjadi. Besar nilai yang diberikan disesuaikan dengan jawaban yang diberikan oleh responden.

\subsection{Pengambilan Data}

Pengambilan data dilakukan kepada 6 responden yaitu mahasiswa sistem informasi yang telah terbiasa menggunakan E-Learning. Para responden diminta untuk melakukan tugas yang telah ditentukan untuk mengetahui apakah terdapat masalah pada tugas tersebut. Berikut merupakan contoh hasil data dari evaluasi yang telah dilakukan.

Tabel 4: Hasil data cari kelas

\begin{tabular}{|c|c|c|c|c|}
\hline \multirow[b]{2}{*}{ No } & \multicolumn{4}{|c|}{ Mencari Kelas } \\
\hline & Gagal/Sukses Alur & Pengujian Masalah & $\begin{array}{c}\text { Keseriusan } \\
\text { Masalah } \\
\end{array}$ & Jenis Masalah \\
\hline 1 & Iya & Tidak ada masalah & 5 & - \\
\hline \multirow[t]{2}{*}{2} & Iya, Mungkin & Responden sedikit & & \\
\hline & & $\begin{array}{l}\text { kebingungan tentang } \\
\text { letak tombol untuk } \\
\text { mengakses menu cari } \\
\text { kelas }\end{array}$ & 4 & $\mathrm{H}$ \\
\hline 3 & Iya & Tidak ada masalah & 5 & - \\
\hline \multirow[t]{2}{*}{4} & Iya, Mungkin & Responden sedikit & & \\
\hline & & $\begin{array}{l}\text { kebingungan tentang } \\
\text { icon yang digunakan } \\
\text { pada menu }\end{array}$ & 4 & $\mathrm{~T}$ \\
\hline 5 & Iya & Tidak ada masalah & 5 & - \\
\hline 6 & Iya & Tidak ada masalah & 5 & - \\
\hline
\end{tabular}

Pada Tabel 4 merupakan contoh dari tabel hasil data evaluasi yang telah didapat dari para responden. Pada tabel menunjukan, apakah alur tugas sukses atau gagal, pengujian masalah, tingkat keseriusan masalah, dan jenis masalah yang didapat. Melalui tabel dapat diketahui bahwa responden ke-dua memiliki kendala mengenai penempatan tombol untuk mengakses menu cari kelas, dan responden keempat memiliki kendala tentang icon yang digunakan pada menu. 


\subsection{Analisis Hasil Evaluasi}

Pada tahap ini, analisis hasil evaluasi dilakukan dengan membuat tabel matriks antara grade dan keseriusan masalah, jenis masalah dan keseriusan masalah, jenis masalah dan grade, nomor tugas dan keseriusan masalah, serta nomer tugas dan jenis masalah. Kemudian ditentukan angka rata-rata dari tabel hasil data dan dimasukkan ke dalam tabel matriks.

\subsection{Kesimpulan dan Saran}

Pada tahap kesimpulan dan saran, ditentukan kesimpulan berdasarkan hasil perancangan interface dan hasil evaluasi interface, serta saran perbaikan dari penelitian ini.

\section{Hasil dan Diskusi}

Prinsip Gamification yang diterapkan pada E-learning terdapat pada fitur Ranking Nilai, Challenge dan Reward. Pada fitur ranking nilai prinsip yang diangkat adalah sistem peringkat, dimana para pengguna mahasiswa dapat bersaing satu sama lain untuk mencapai peringkat tertinggi. Selanjutnya pada fitur challenge mahasiswa dapat mengerjakan soal-soal yang diberikan oleh dosen dengan imbalan berupa poin yang dapat dikumpulkan dan ditukarkan dengan Reward tertentu. Selain fitur dengan prinsip Gamification, E-learning juga menyediakan fitur yang dibutuhkan dalam menunjang proses pembelajaran seperti fitur Materi, Tugas, Ujian, dan fitur penunjang lainnya seperti profil dan notifikasi. Fitur-fitur tersebut diharapkan dapat memicu minat dan motivasi mahasiswa terhadap pembelajaran, hal ini juga bersamaan dengan fungsi dan pengertian dari gamification yang mengangkat prinsip permainan ke situasi lain untuk meningkatkan minat pengguna.

Adapun Hasil dan diskusi ini akan membahas mengenai contoh hasil rancangan interface E-Learning berbasis Gamification dan analisis data hasil evaluasi menggunakan metode Cognitive Walktrough.

\subsection{Contoh Hasil Rancangan Interface}

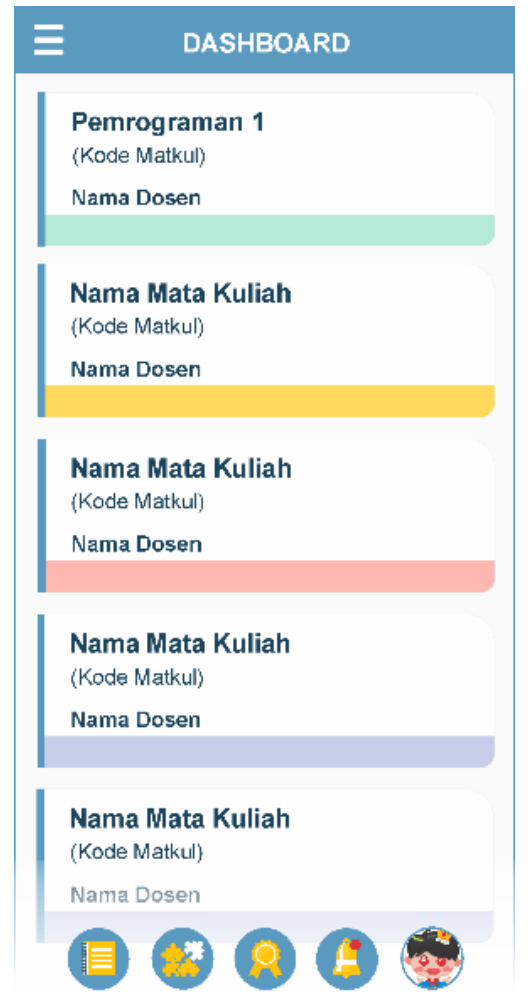

(a)

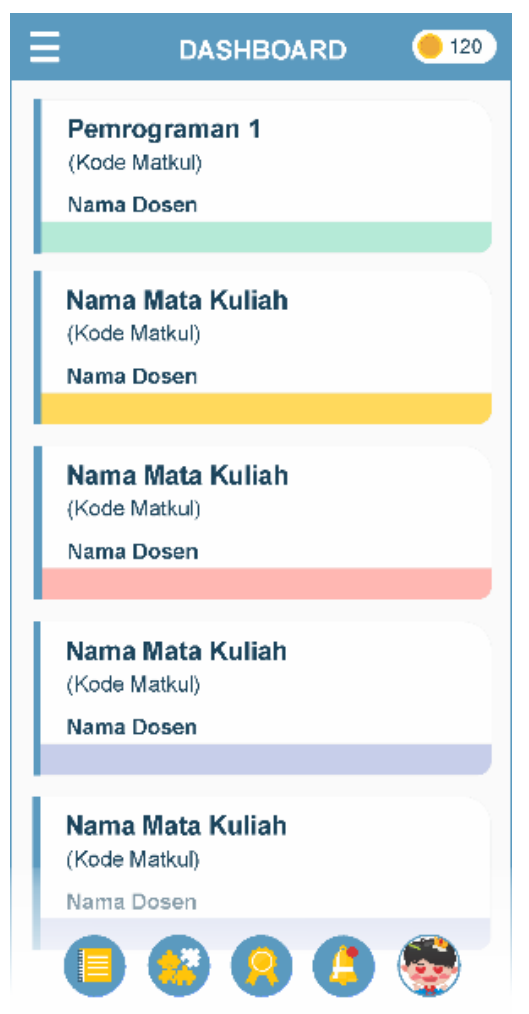

(b)

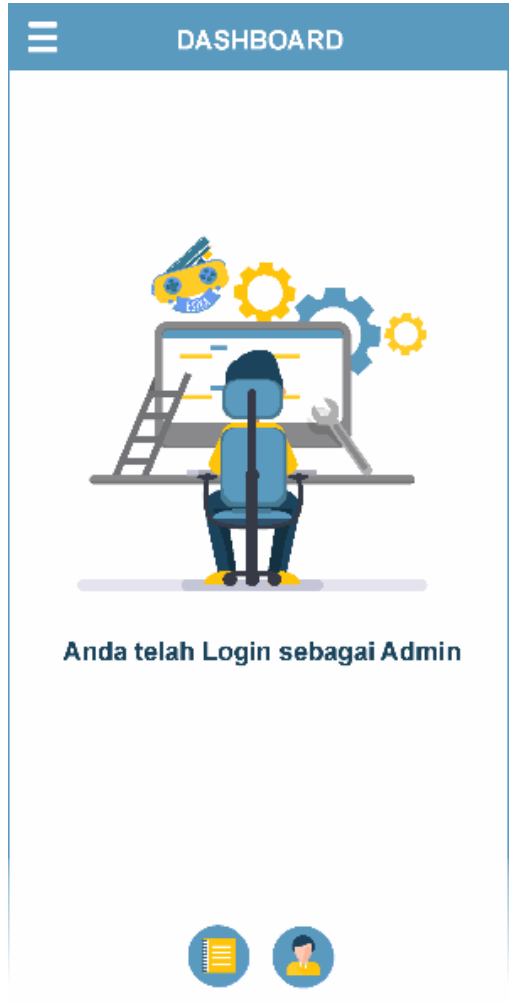

(c)

Gambar 4: Dashboard; Dosen (a), Mahasiswa (b), Admin (c) versi Mobile 
Pada Gambar 4 menampilkan Dashboard dari setiap user, Gambar 4 (a) merupakan Dashboard Dosen, pada dashboard ini memiliki menu untuk mengakses Dashboard, Challenge, reward, notifikasi, dan profil. Gambar 4 (b) merupakan Dashboard Mahasiswa, menu yang diberikan hampir sama dengan Dashboard dosen akan tetapi terdapat informasi poin yang dimiliki user pada pojok kanan atas. Sedangkan pada Gambar 4 (c) merupakan Dashboard admin, pada dashboard ini hanya memiliki menu untuk mengakses Dashboard dan profil.

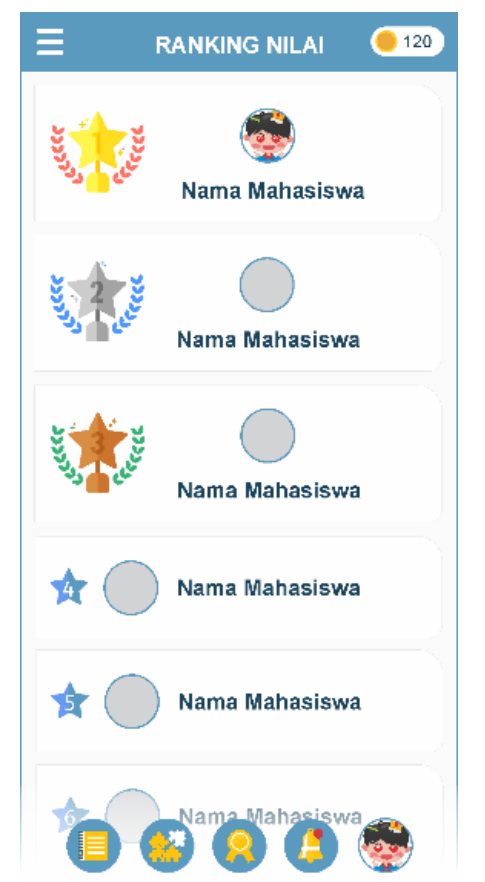

Gambar 5: Ranking Nilai versi Mobile

Pada Gambar 5 merupakan halaman dari ranking nilai. Pada halaman ini menampilkan informasi peringkat atau rank dari peserta yang berada didalam kelas. Mahasiswa dengan peringkat 1 sampai 3 akan mendapatkan badge berbeda dengan peringkat yang lain. 


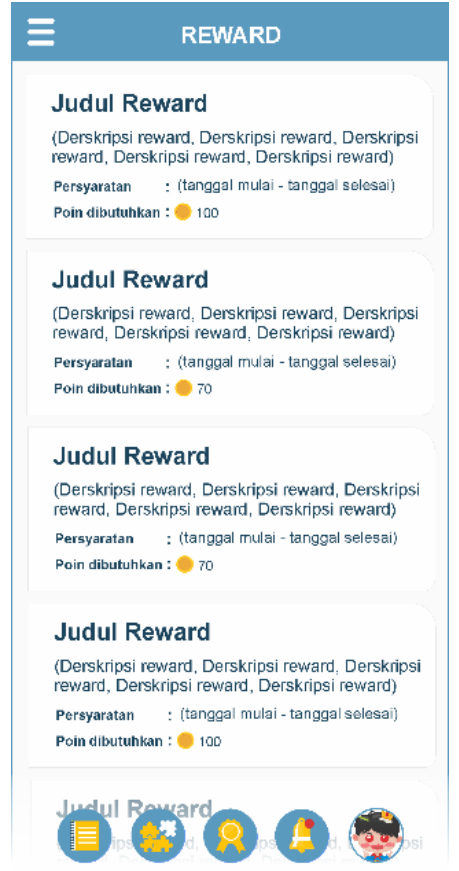

(a)

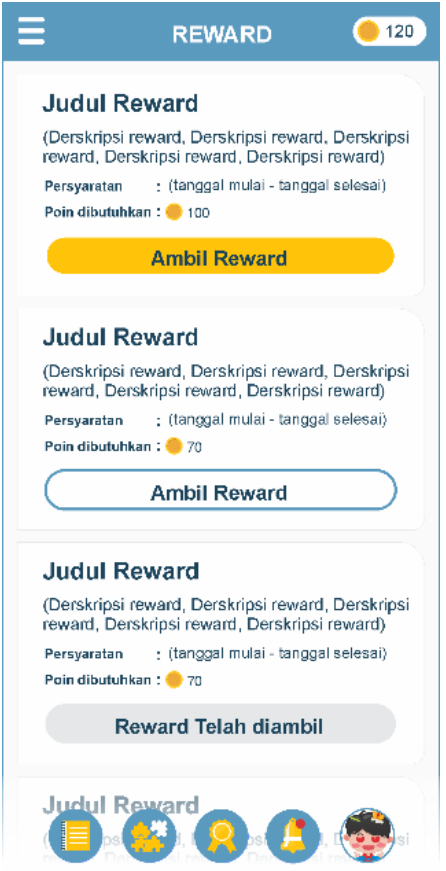

(b)

Gambar 6: Reward; Dosen (a), Mahasiswa (b) versi Mobile

Pada Gambar 6 Menampilkan halaman reward. terdapat informasi mengenai judul setiap reward, deskripsi reward, dan bobot poin yang dibutuhkan untuk mengambil setiap reward. Gambar 6 (a) merupakan halaman reward yang diakses oleh dosen, sedangkan Gambar 6 (b) merupakan halaman reward yang diakses oleh mahasiswa, pada halaman reward yang diakses mahasiswa terdapat tombol untuk ambil reward, dan jika reward telah diambil maka tombol akan di non-aktifkan. Reward hanya dapat diambil dengan memenuhi peryaratan dan poin yang dibutuhkan, poin didapatkan melalui pengerjaan challenge yang telah diberikan oleh dosen.

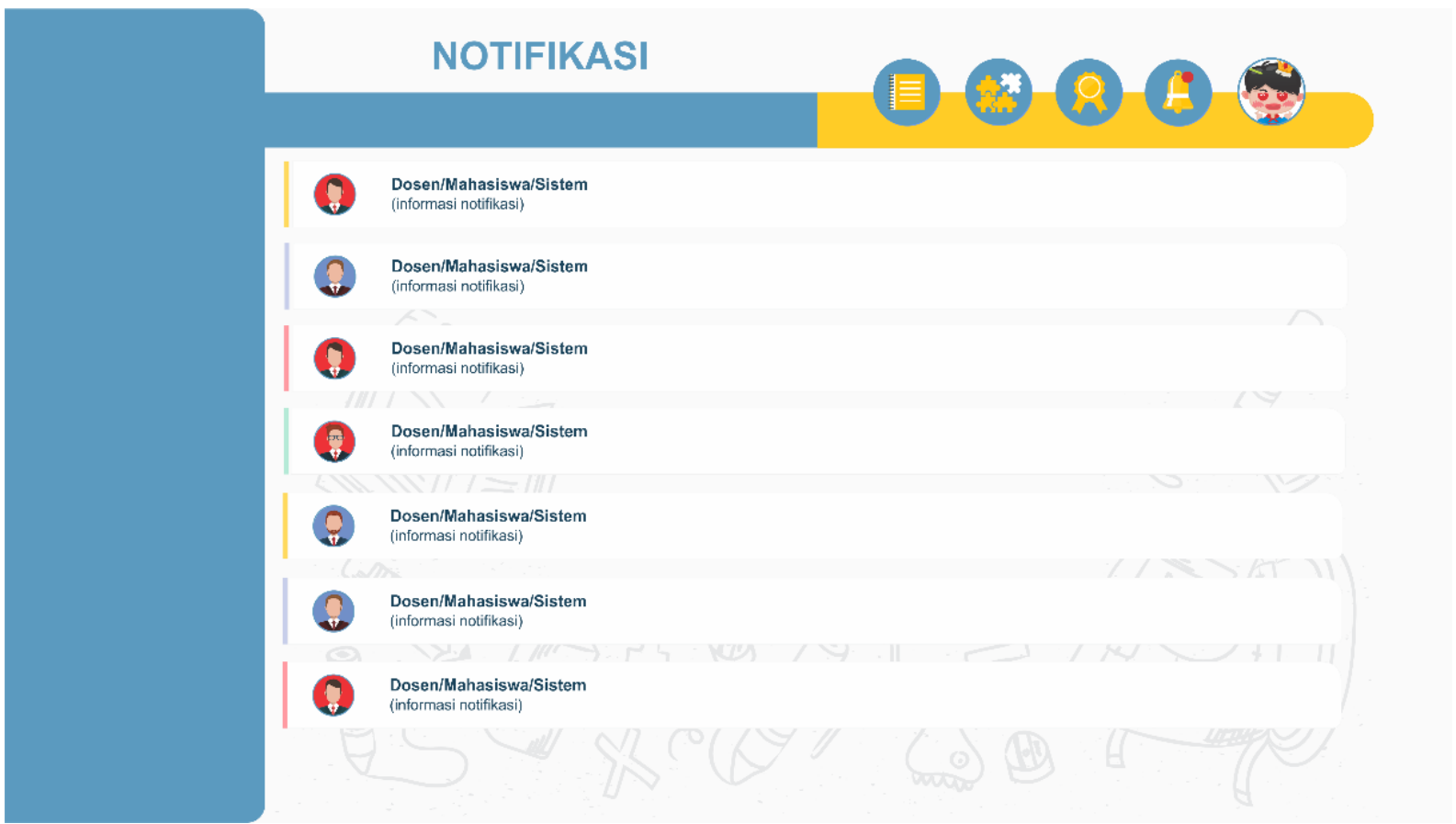

Gambar 7: Notifikasi versi Desktop

Gambar 7 adalah halaman yang berisikan notifikasi yang terdapat pada sistem informasi ESIKA. 


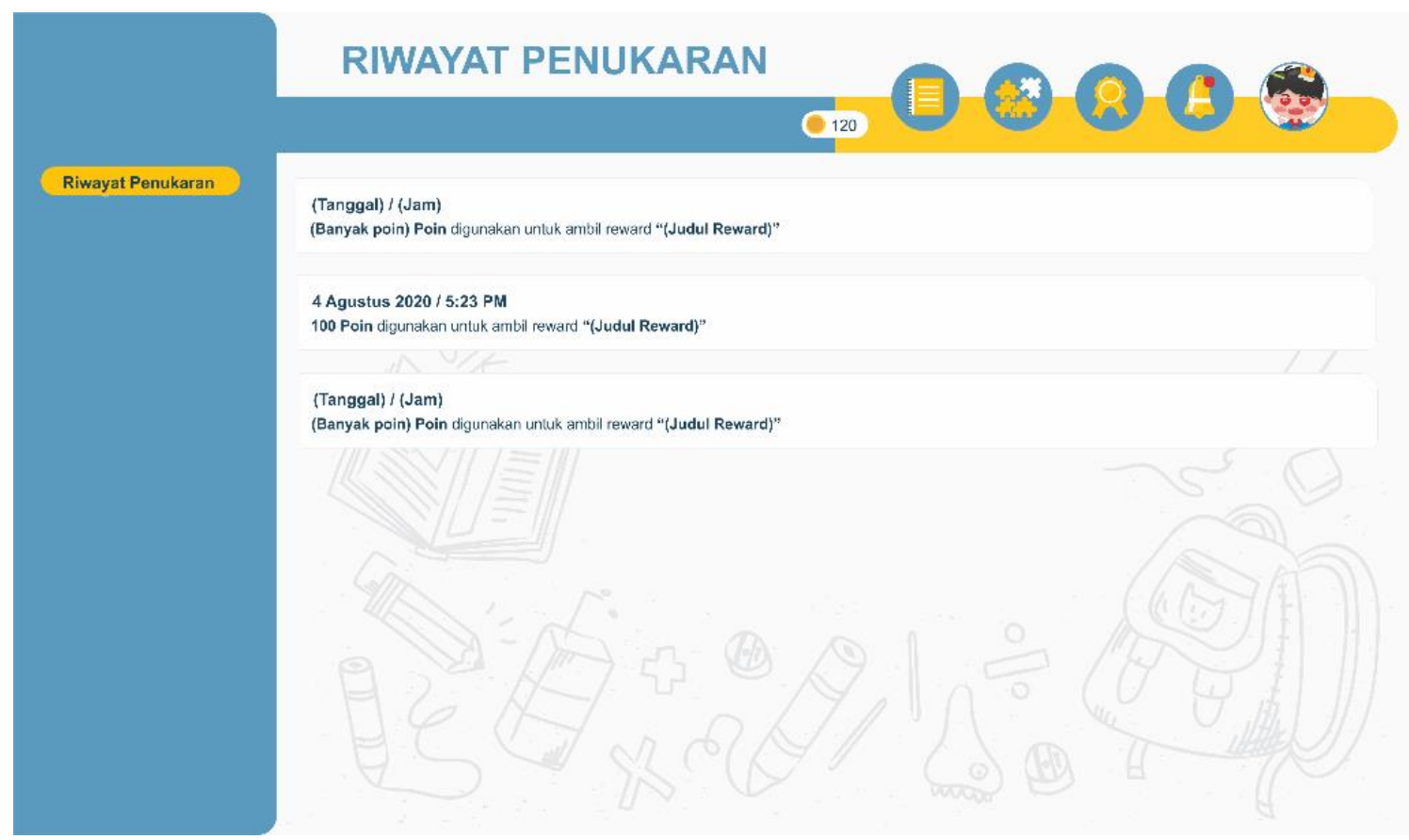

Gambar 8: Riwayat Penukaran versi Desktop

Gambar 8 merupakan halaman yang berisikan informasi riwayat penukaran poin dan reward yang telah dilakukan.

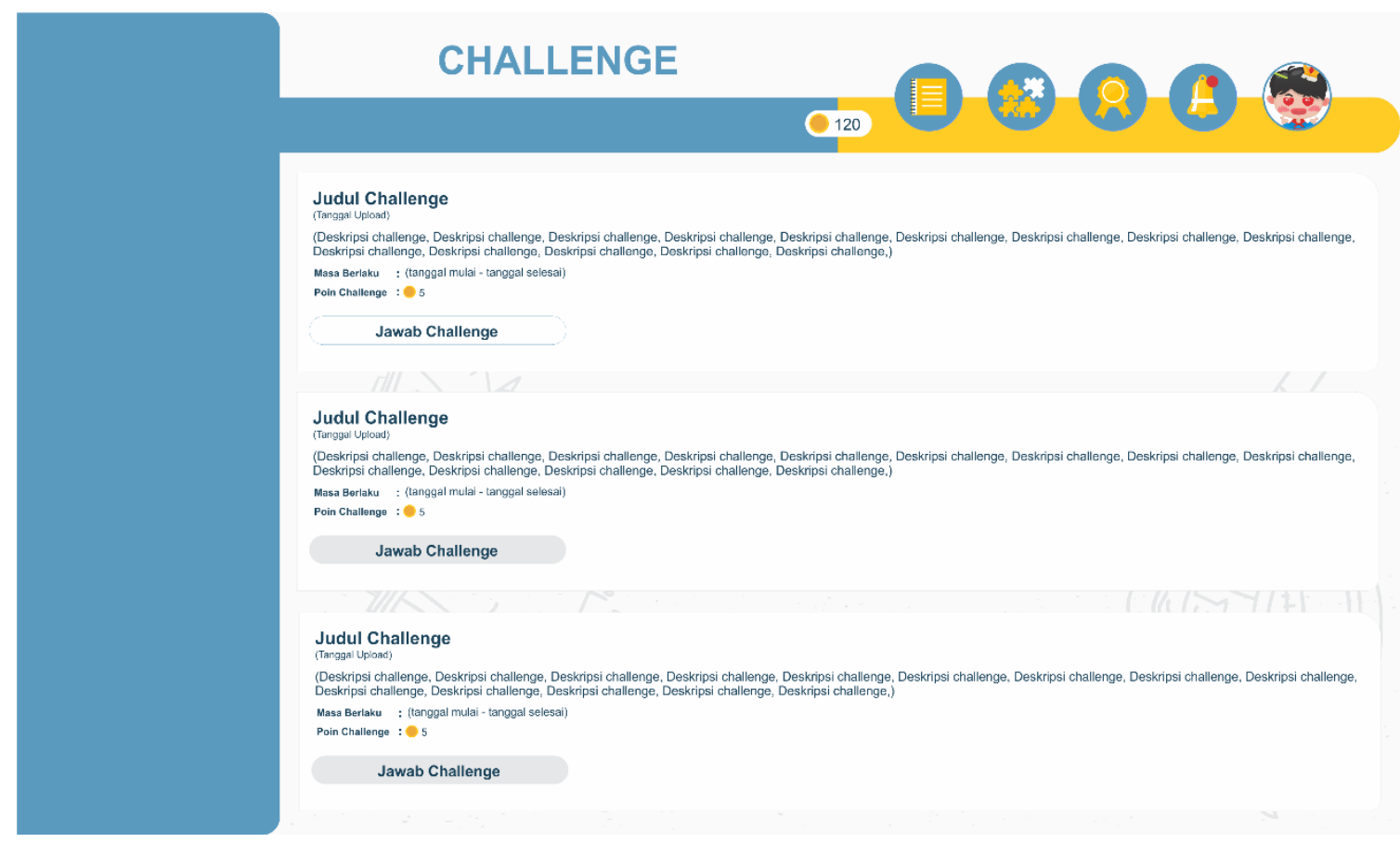

Gambar 9: Challenge versi Desktop

Pada Gambar 9 ditampilkan menu challenge. Pada menu ini berisikan fitur challenge yang dapat dikerjakan oleh pengguna untuk mendapatkan imbalan berupa poin. Informasi yang ditampilkan pada setiap challenge, yaitu judul challenge, tanggal dibuat, deskripsi challenge, masa berlaku, dan poin yang ditawarkan oleh challenge. Pengguna dapat mengerjakan challenge dengan memilih tombol jawab 
challenge dan kemudian menjawab challenge tersebut, jika jawaban benar maka poin akan didapatkan oleh pengguna, dan jika jawaban salah maka poin tidak didapatkan.

\subsection{Analisis Data Hasil Evaluasi}

Setelah hasil data didapat, kemudian dianalisis kedalam matriks untuk mendapatkan hasil evaluasi dan kesimpulan dalam evaluasi. Berikut merupakan tabel matriks dari data hasil evaluasi.

Tabel 5: Matriks Grade dan Keseriusan Masalah

\begin{tabular}{lllllll}
\hline \multirow{2}{*}{ Grade } & & \multicolumn{3}{c}{ Keseriusan Masalah } & \multicolumn{1}{c}{$\mathbf{4}$} \\
\hline 1 & & $\mathbf{1}$ & \multicolumn{2}{c}{$\mathbf{3}$} & 0 \\
2 & 0 & & 0 & 0 & 0,33 \\
3 & 0 & 0 & 0 & 0,11 & 0,17 \\
4 & 0 & 0 & 0,17 & 0 \\
\hline
\end{tabular}

Pada Tabel 5 dijelaskan hasil dari rata-rata masalah paling banyak muncul pada Grade 3 dengan tingkat keseriusan rendah (4) sebesar sebanyak 0,33, sedangkan tingkat keseriusan masalah tertinggi terdapat pada tingkat menengah (3), tetapi angka yang ditunjukan bukan angka yang besar dan tidak akan terlalu mempengaruhi sistem.

Tabel 6: Matriks Jenis Masalah dan Keseriusan Masalah

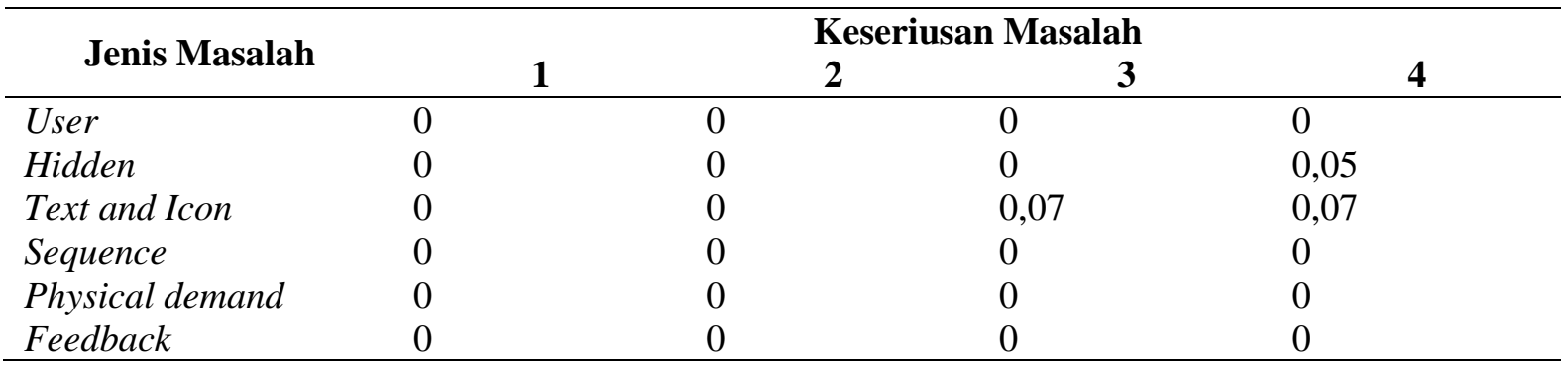

Pada Tabel 6 diketahui bahwa jenis masalah yang paling banyak muncul dan dengan tingkat keseriusan masalah tertinggi yaitu pada Text and Icon, akan tetapi angka hanya menunjukkan sebesar 0,07 sehingga tidak akan terlalu mempengaruhi jalannya sistem.

Tabel 7: Matriks Jenis Masalah dan Grade

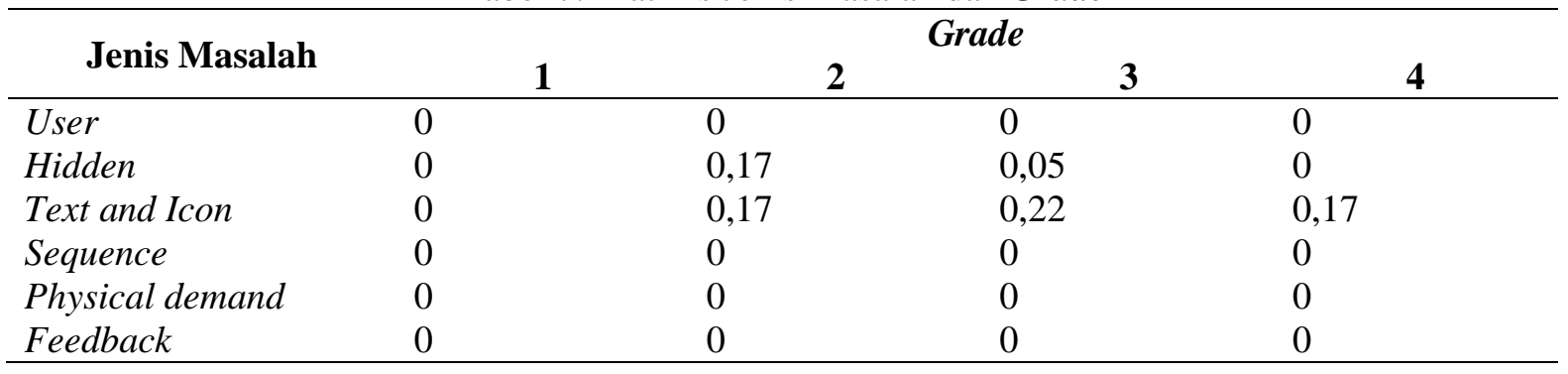

Pada Tabel 7 dapat diketahui bahwa jenis masalah yang paling banyak muncul, yaitu Text and Icon, yang muncul pada Grade 4, 3, dan 2. 
Tabel 8: Matriks Nomor Tugas dan Keseriusan Masalah

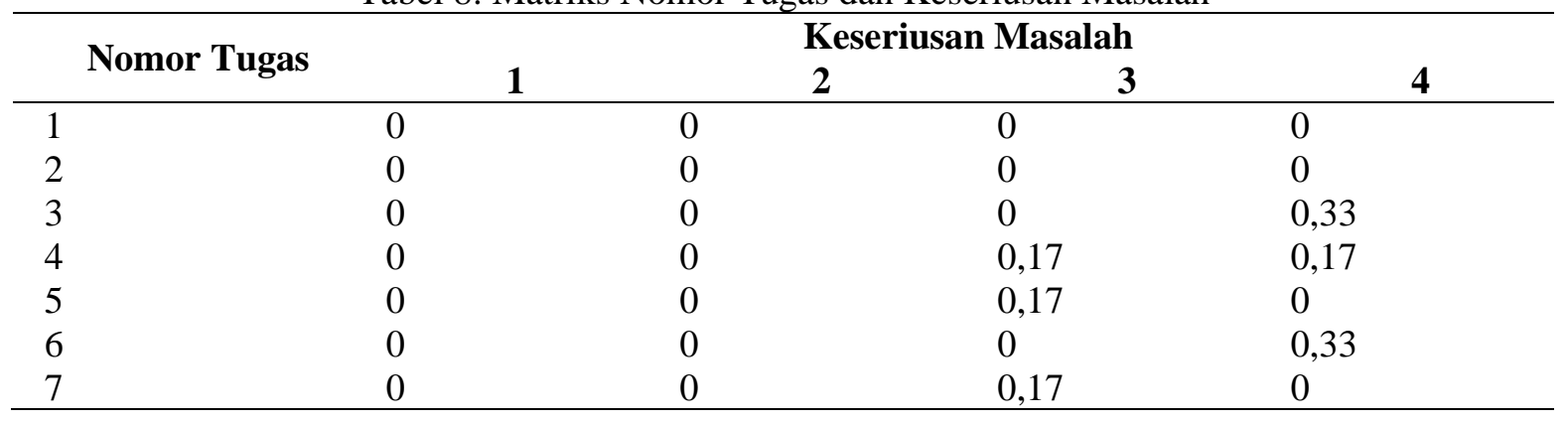

Pada Tabel 8 dapat diketahui masalah paling sering muncul pada tugas nomor 3, yaitu cari kelas dengan angka sebesar 0,33 , dan tugas nomor 6 , yaitu kerjakan challenge sebesar 0,33 . Akan tetapi masalah muncul pada tingkat keseriusan yang rendah (4), sehingga tidak akan mempengaruhi jalannya sistem.

Tabel 9: Matriks Nomor Tugas dan Jenis Masalah

\begin{tabular}{lllllll}
\hline \multirow{2}{*}{ Nomor Tugas } & & \multicolumn{5}{c}{ Jenis Masalah } \\
& User & Hidden & Text \& Icon & Sequence & $\begin{array}{c}\text { Physical } \\
\text { Demand }\end{array}$ & Feedback \\
\hline 1 & 0 & 0 & 0 & 0 & 0 & 0 \\
2 & 0 & 0 & 0 & 0 & 0 & 0 \\
3 & 0 & 0,17 & 0,17 & 0 & 0 & 0 \\
4 & 0 & 0,17 & 0,17 & 0 & 0 & 0 \\
5 & 0 & 0 & 0,17 & 0 & 0 & 0 \\
6 & 0 & 0 & 0,33 & 0 & 0 & 0 \\
7 & 0 & 0 & 0,17 & 0 & 0 & 0 \\
\hline
\end{tabular}

Pada Tabel 9 dapat disimpulkan bahwa jenis masalah yang paling sering muncul, yaitu Text and Icon, yang muncul pada tugas nomor 3, 4, 5, 6, dan 7. Kemudian juga terdapat jenis masalah Hidden yang muncul pada tugas nomor 3 dan 4 .

\section{Kesimpulan}

Berdasarkan penelitian yang telah dilakukan, yaitu perancangan desain aplikasi E-learning berbasis gamification dan evaluasi desain hasil rancangan, dapat disimpulkan bahwa:

- Berdasarkan hasil evaluasi dapat diketahui bahwa tidak terdapat masalah pada tugas dengan Grade 1, dan tidak banyak masalah yang muncul di tingkat keseriusan yang tinggi pada Grade 2 sehingga dapat disimpulkan bahwa tidak ada masalah berarti pada fitur utama sistem.

- Data hasil evaluasi menunjukan bahwa masalah yang paling banyak muncul, yaitu Text and Icon, meskipun angka yang ditunjukkan tidak terlalu besar. Hal ini sebaiknya dapat diperhatikan agar tidak banyak masalah yang muncul di kemudian hari.

\section{Ucapan Terima Kasih}

Penulis mengucapkan terima kasih kepada orang tua, dosen pembimbing, rekan-rekan dari Program Studi Sistem Informasi Institut Teknologi Kalimantan. Penulis juga mengucapkan terima kasih kepada Bapak pembimbing, yaitu M. Gilvy Langgawan Putra, S. Kom., M. MT. yang telah memberikan kesempatan kepada penulis sehingga dapat melakukan penelitian ini. Penulis mengucapkan terima kasih pula kepada seluruh pihak yang telah membantu kelancaran dalam penelitian dan penulisan jurnal ini. 


\section{Daftar Pustaka}

Akbar, R. A., Az-Zahrah, H. M., dan Brata, K. C. (2019) 'Evaluasi User Experience pada Game PUBG MOBILE menggunakan metode Cognitive Walkthrough', Jurnal Pengembangan Teknologi Informasi dan Ilmu Komputer, Vol. 3, No. 2: 1660-1668.

Amriani, A. (2013) 'An empirical study of gamification impact on e-learning environment' dalam Proceedings of the $3^{\text {rd }}$ International Conference on Computer Science and Network Technology, Dalian, Cina: ICCSNT.

Baldauf, M. B. (2017) 'Mobile and gamified blended learning for language' dalam MUM '17: Proceedings of the 16th International Conference on Mobile and Ubiquitous Multimedia, Stuttgart, Germany: MUM.

Bligard, L. (2013) 'Enhanced Cognitive Walkthrough: development of the Cognitive Walkthrough method to better predict, identity, and present usability problems', Advance in Human-Computer Interaction, Vol. 2013.

Darmawan, A. (2020) Penerapan Konsep Gamification pada Aplikasi Pembelajaran Ilmu Agama berbasis Android, Surabaya: Universitas Dinamika.

Malas, R. H. (2016) ‘A gamified e-learning design model to promote and improve learning', International Review on Computers and Software (I.RE.CO.S.), Vol. 11, No. 1: 8-19.

Pratama R. P., Saputra, K.O., dan Khrisne, D. C. (2019) 'Penerapan gamification pada sistem informasi manajemen ruang baca', Jurnal SPEKTRUM, Vol. 6, No. 3: 148-153.

Sari, B. H. (2016) 'Penerapan konsep gamification dalam merancang aplikasi', Jurnal Ilmiah DASI, Vol. 17, No. 4: $32-37$.

Setiyawan M., Winarno, W. W., dan Sunyoto, A. (2019) 'Implementasi gamification pada aplikasi perkuliahan mahasiswa dengan metode Feature Driven Development (Studi Kasus: AMIK Cipta Darma Surakarta)', Jurnal Ilmiah IT CIDA, Vol. 5, No. 1: 16-30.

Solikhin, M. P., Jonemaro, E. M. A., dan Akbar, M. A. (2018) 'Evaluasi User Experience pada game Left 4 Dead 2 menggunakan Cognitive Walktrough', Jurnal Pengembangan Teknologi Informasi dan Ilmu Komputer, Vol. 2, No. 7: 2619-26125. 